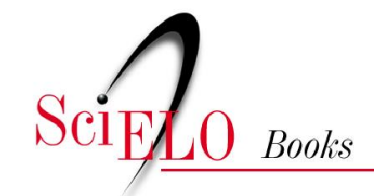

\title{
1 - What is a telephone? \\ capitalist civilization and consumption
}

\author{
Bernardo Sorj
}

SORJ, B.brazil@digitaldivide.com: confronting inequality in the information society [online]. Rio de Janeiro: Centro Edelstein de Pesquisa Social, 2008. What is a telephone? capitalist civilization and consumption. pp. 12-18. ISBN 978-85-99662-48-9. Available from SciELO Books <http://books.scielo.org>.

\section{(1) (1) (1)}

All the contents of this chapter, except where otherwise noted, is licensed under a Creative Commons Attribution-Non Commercial-ShareAlike 3.0 Unported.

Todo o conteúdo deste capítulo, exceto quando houver ressalva, é publicado sob a licença Creative Commons Atribuição Uso Não Comercial - Partilha nos Mesmos Termos 3.0 Não adaptada.

Todo el contenido de este capítulo, excepto donde se indique lo contrario, está bajo licencia de la licencia Creative Commons Reconocimento-NoComercial-CompartirIgual 3.0 Unported. 


\section{1 - What is a Telephone? Capitalist Civilization and Consumption}

In Brazil, at the beginning of the 1990s, a cellular telephone line cost US $\$ 12,000$ and a cellular telephone itself cost US \$2,000. The number of people with cellular phones was small and owners of cellular phones liked to be conspicuous about them, constantly gesticulating with their phones in their hands in public situations. Cellular phones were almost never used and their utility had an inverse relationship to their price. They were above all symbols of social status.

In the late 1990s, with the privatization of telecommunications, new companies introduced cellular telephones to the Brazilian markets on a large scale, offering cellular phone lines at no cost. At the time, a fixed telephone line cost ten to twenty times the value of a monthly minimum wage. In one of my sociology classes, students argued that the cellular phone companies were using advertising to convince people to buy unnecessary products designed only for individual use and with a much higher per-minute price, in place of expanding the existing telephone system for family use. I argued that the expansion of the cellular telephone system was spectacular, that we shouldn't assume that the people are so easily manipulated, and that the widespread adoption of cellular phones should be explained leaving aside ideological prejudices in relation to current government (which favored privatization). The debate created a tense and polarizing atmosphere in the classroom that was only broken with the proposal of a research project on the use of cellular telephones among low-income Brazilians.

The results of the research were surprising even for me. The people we interviewed said that cell phones were an important tool for improving chances in the employment market. In a city like Rio de Janeiro, where more than half of the population - and among the low-income populations, the large majority - work informally without a contract carrying out ad hoc services, the telephone is a fundamental tool for setting up job opportunities. With the introduction of the cellular telephone, carpenters, painters, plumbers, housekeepers, locksmiths, bricklayers, manicurists, and taxi drivers increased enormously their chances of being located when work opportunities arose.

Before the cellular telephone, the only means of contact for informal workers was generally the home phone of some neighbor who offered the favor of taking messages. Still, it could be argued that for these sectors of the population, a standard telephone line would be more convenient as the cost of calls is lower than the cellular telephone, but this was not the case. Even later when telephone lines were made available at no cost, the low-income population continued to acquire cellular telephones. The explanation was simple: a standard telephone does not offer the mobility that the cellular telephone offers. An autonomous worker with a cellular phone can be reached easily, thus maximizing the use of his or her time. Mobility also offered other advantages for workers who need to be reachable. For example, low- 
income mothers, who provide housekeeping services in organizations or companies without access to a telephone, could rest easier leaving their small children with a neighbor knowing that they could be contacted in case of necessity.

The higher cost of mobile phone calls remains an issue. Both the per-call and monthly fees are higher for cellular telephones than for standard telephones. The low-income population responded to this problem by opting for prepaid cellular service without monthly fees (although prepaid cards have expiration dates that amount to a minimum fee). Since calls made from prepaid cellular phones are much more expensive than call made from phones with traditional service plans, the solution was simple: cellular phones became a tool only for receiving calls. In Brazil, the fees for incoming calls to cellular phones are charged to the caller rather than the recipient. Low-income people continue to use public phones to make phone calls and make calls from cellular phone only in cases of urgency.

The expansion of cellular telephone in Brazil in the past few years has been impressive. In 1994 there were 800,000 cellular telephone accounts. By the end of 2002 there were 32 million. However the projections for universal cellular service in Brazil have become overly optimistic, and recently, companies have reduced their expansion plans. The current prediction is that at most, only a third of the Brazilian population will have a cellular telephone in coming years. What happened to the rapid growth? The barrier of income distribution makes cellular telephones, even with prepaid service plans, inaccessible to Brazilians at the lowest income levels. As we will see in the coming chapters, the market sometimes creates miracles but only to people who are able to reach certain income levels. The poorest sectors of the population will need the leverage of state intervention to gain access to communication services.

The cellular telephone is an excellent example of the diverse dimensions that should be considered in the analysis of the social impact of products or services consumed in contemporary society. As mentioned earlier, the cellular telephone, like the standard telephone, was initially an object of conspicuous consumption, used ostentatiously as a symbol of the class or status of their owners. Even in the present day, the initial dimension of social status has not disappeared. The telephone industry continues to periodically release more expensive products, usually with small modifications in design or function, that permit high income consumers to feel that they can use their telephones as tools of social differentiation.

The expansion of cellular telephony involves what is known as the product cycle, in which initially a product is introduced in small quantities with high price and is later massproduced, permitting access of a large part of the population. This process is accompanied by a social product cycle in which a new product initially reaches only those at the highest income levels and later, with mass production and price reduction, is disseminated throughout all sectors of the population. Thus, the dynamics of technological innovation reinforce social inequality in the initial stages, when a product reaches only the highest income sectors of the population, and later plays an equalizing role through mass production. 
The international product cycle, the distribution of new products on an international scale, involves a different type of social product cycle in developing countries. Many products reach the highest classes and later the middle classes, but these products may take a long time to reach the lowest classes and in some cases never do. When the product cycle is incomplete, excluding certain sectors of the population from new technological innovation, it helps to consolidate and create new forms of social inequality.

In many cases, the dynamics of the social product cycle play a role in determining the product utility. The diffusion of a product is in some cases a condition of its practical use. This is due either to the availability of necessary infrastructure, as is the case with paved roads and highways whose development depends on a minimum number of cars in circulation; or the existence of other users to permit interaction, as with case of the telephone, which requires a minimum number of telephone users.

\section{Capitalist Civilization and Consumption}

In recent decades, theories regarding the consumption society have focused on the analysis of consumption objects as a symbolic system -a type of language in which consumption objects are symbols of social status. Thus the use value of a product is viewed not as a consequence of its material utility, but rather as its capacity to indicate social distinctions. The differentiation of products follows the differentiation between social groups, and the middle and upper classes in particular mark their social status through objects and an aesthetic to which only they have access or can afford.

Theories that connect social stratification with consumption do describe a dimension of social reality. But this is only one aspect and, in general, a secondary component of the act of consumption. These theories ignore the central characteristic of consumption in contemporary society: the majority of consumption products are embedded expressions of the scientific and technological knowledge of society, which have become prerequisites for social integration in everyday life, as much in terms of quality of life as in chances for social participation in general and entrance into the workforce in particular. Consumption as a mechanism of social distinction is important at the margins of the productive sector and much advertising focuses primarily on brands of mass consumption. In fact many consumption products like home water, electricity, and telephone lines, which were also once objects of conspicuous consumption, are now considered commodities or public goods.

The critiques of the McDonaldization of the world and the alienating role of trademarks epitomized by Nike refer to very limited aspects of the world of consumption. For the poorest populations of the planet, globalization is not the expectation of eating at McDonald's or wearing Nike, it is access to food, water, electricity, appliances, radio, television, telephone, Internet, antibiotics, books, cinema, CD players, cars, travel, and all those products 
and services to which persons opposed to globalization would not deprive themselves. These products bring material quality of life to such a level that, for instance, poor persons in France today enjoys a better material quality of life than the richest French did 200 years ago. Be it to treat a toothache or an infection (in the 19th-century Nathan Rothchild died, unable to get treatment for a boil), to access information, to deliver children, to lie down in a comfortable bed, or to have a good heating or cooling system to face winter or summerconsumption goods are disseminated because they facilitate life, not through the brainwashing by advertisers.

Capitalist consumption civilization has enormous problems, but the principal challenges are in the areas of environmental impact and the relationship between advanced technologies and democracy and ethics. Such is the case, for example, with the problems surrounding genetic engineering, which raises questions about the control and mercantilization of life and the possible effects of mutation of the human species or, as we will see, information technology with its potential to destroy privacy.

Social science lacks comprehensive theories regarding the relationship between consumption and society. Economics, with its nearly exclusive focus on production, has reduced consumption to a simple question of personal choice in which the consumer is free to choose based on his or her personal priorities. Sociological theories, such as those mentioned earlier, were developed to oppose this perspective by showing that consumer options are constructed socially and that individuals make choices based on the esthetic standards of their social group.

In past decades some economists have tried to develop limited scope theories about consumption. For example, they have shown that levels of consumption or savings is related to the life cycle, and they have introduced some very general hypotheses on the way individuals structure their consumption by prioritizing basic necessities (such as food), and later satisfying necessities they consider secondary. These are important but partial efforts and economists are still far from a consumption theory with the same explanatory capacity as the theoretical frameworks they have developed to analyze the logic of the productive system.

The difficulties that social science encounters as it attempts to analyze the role of consumption in capitalist civilization originates with a false starting point, which radically separates the processes of production and consumption. Treating both spheres as autonomous realities results in a search for separate explanations for each one. But consumption is one of the constitutive elements of the productive system, not only because it allows the flow of production but also because the majority of products consumed transform the context of production, workers productivity, and society. Even Marx, who tried to relate production and consumption, made a major analytical error by reducing work to a commodity. He didn't grasp that labor is a very particular commodity, one that not only is capable of fighting for its market value, but which is transformed through the process of consuming other commodities.

When economists introduced the notion of human capital, they took the first step toward recognizing that investments in consumption goods, like education, have a direct impact on 
the production process, both directly -increasing labor productivity-, and indirectly promoting scientific and technological innovation. But human capital is only one of the mechanisms through which consumption products affect production To the extent that they increase longevity, facilitate locomotion, permit communication between workers and their private lives, and reduce time spent on housework, consumer products directly impact the productive system, transform society, and become essential to social life.

In short, consumption products, particularly within capitalist society, but also throughout all human history, incorporate and condense as much technology and knowledge as the instruments used in the production process. Social relations are affected and transformed through consumption as much as through production. The introduction of the cell telephone provides a simple example of the multiplicity of impacts of consumption goods in social relations.

\section{What is a cellular telephone?}

In the same way that some technologies can transform the productive system, that is, they have a capacity to penetrate the most diverse dimensions of social organization, some consumption products, especially those with embedded technology, penetrate and change diverse patterns of sociability. The simple change from fixed to mobile telephone offers some good examples of how consumption products play a role in increasing possibilities for individualization as well as in creating new forms of social control.

Even homes with more than one telephone line used the fixed telephone line collectively, while the cellular phone is used individually. Fixed phones facilitated control over phone calls between family members since anyone could answer a call (the classic question when someone arrived at home was, "Did anyone call?"). The telephone was sometimes a source of family crisis, especially when children became adolescents and spent hours on the phone. The collective use of telephones even had an impact on statistics: the relevant data on availability of telephones was the number of phones per household, whereas with cellular phones it is the number per individual.

The cellular telephone permits greater individualization through the elimination of control over calls by family members, and by increasing the communication spaces that are not controlled by the immediate environment. Children and adolescents can communicate without their parents knowing who called and everyone can talk from spaces where husbands, wives, mothers, and fathers, cannot overhear, deliberately or not. On the other hand, the fact that people have their cellular telephones with them all the time creates a new potential for social control and the loss of privacy. For example, one of the major initial consumers of cellular telephones among the middle-class were parents buying telephones for their adolescent children in order to maintain control at a distance. 
When someone calls a fixed phone, the first question is, "How are things?" With cellular phones, the first question is, "Where are you?" In the past, reaching someone on the telephone meant at the same time knowing exactly where the person was located. The cellular permitted a separation between spoken communication and a person's location or to put it another way, to locate a person, you no longer need to know or find out their location. With cellular phones, the act of locating a person does not tell you where the person is located, which has the effect of dissociating communication from location. But this possibility, which limits control over personal privacy, could be eliminated in the future when all telephones come with cameras that transmit images, and GPS systems that identify the location of both the caller and the call receiver.

In the work sphere, the cellular telephone allows people to be located at any time and in any place, and, as we will see ahead, when combined with the Internet, has the effect of bringing greater flexibility to work through an end to the separation between work and private life. In place of the promised "end of work" trend of the eighties, we find an increasing colonization of private space and intimacy through the constant invasion of calls and messages outside of business hours. 


\section{Box B - Necessity and Consumption}

Behind a large part of the social criticism surrounding contemporary consumption society there is a view that there are "real necessities," while other necessities are products of advertising, exhibitionism and ostentation.

Anthropology has criticized the notion that consumption can be reduced to a natural notion of necessity. Culture always permeates tastes and defines which products are appropriate for consumption. For example, there is nothing natural about the preference in some cultures for beef while others prefer dog meat. Anthropology also shows that consumption objects are more than instruments of social distinction for dominant groups, since they are used equally to mark the identities of minorities and underprivileged groups, and to express social protest.

Though ostentation has always characterized, and will continue to characterize, the lives of the dominant classes, modern society is a society of consumption not because of advertising but because the large majority of consumption products are pre-conditions of access to health, education, work, and sociability.

It is important to remember that the majority of consumption products are used because, within the context of contemporary society, they are useful. They represent technologies that allow improvements to the quality of life and social integration. After they have reached a certain level of dissemination in society not having them means social ostracism.

Most of the negative impacts of mass consumption product are related to the paradoxical and unexpected consequences they produce. For example, the car facilitates transport of an individual from one place to another, but today in many cities, an excess of cars makes the bicycle a faster mode of transportation and a way to reduce the pollution that cars cause. New medicines can save lives but their effects on the human gene pool could be disastrous. New seeds can increase production but can also have irreversible negative impact on biodiversity. Or, as we will show, with the case of the information society, databases containing patient medical histories or credit card purchase records can save lives or reduce the risks involved with carrying money, but they generate information on people's private lives that could lead to control over privacy. 